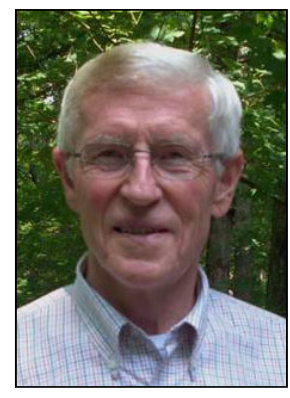

THE ECONOMIC PAMPHLETEER

JOHN IKERD

\title{
The future of food: Separation or integration?
}

Published online February 13, 2019

Citation: Ikerd, J. (2019). The Economic Pamphleteer: The future of food: Separation or integration? Journal of A griculture, F ood Systems, and C ommunity D evelopment, 8(4), 9-12. http:// dx.doi.org/ 10.5304/ jafscd.2019.084.002

Copyright ( 2019 by the Author. Published by the Lyson Center for Civic Agriculture and Food Systems. Open access under CC-BY license.

Tn a previous Economic Pamphleteer column, 1 I wrote of a battle for the future of food and farming (see Ikerd, 2018). The battle is between those attempting to fix the current agri-food system versus those attempting to replace it. The defining question is whether agriculture can be separated from nature and society or instead must be integrated with nature and society. I used hydroponics and concentrated animal feeding operations

John Ikerd is professor emeritus of agricultural economics, University of Missouri, Columbia. He was raised on a small farm and received his BS, MS, and PhD degrees from the University of Missouri. He worked in the private industry prior to his 30-year academic career at North Carolina State University, Oklahoma State University, the University of Georgia, and the University of Missouri. Since retiring in 2000, he spends most of his time writing and speaking on issues of sustainability. Ikerd is author of six books and numerous professional papers, which are available at http:/ / johnikerd.com and http:/ / faculty.missouri.edu/ ikerdj/ as examples of attempts to separate or insolate agricultural production from the vagaries and fragilities of nature and the sensitivities and vulnerabilities of society. Synthetic proteins, manufactured from neither plant nor animal tissue, is perhaps a radical example of the separation currently promoted by some food futurists (Locke, 2016).

Admittedly, separating, or at least insulating, some intensive systems of plant and animal production from nature reduces their most

Why an Economic Pamphleteer? Pamphlets historically were short, thoughtfully written opinion pieces and were at the center of every revolution in western history. I spent the first half of my academic career as a freemarket, bottom-line agricultural economist. During the farm financial crisis of the $1980 \mathrm{~s}$, I became convinced that the economics I had been taught and was teaching wasn't working and wasn't going to work in the futurenot for farmers, rural communities, consumers, or society in general. Hopefully my "pamphlets" will help spark the needed revolution in economic thinking. 
apparent negative ecological and social externalities. Separation may also reduce production risks and increase economic efficiency. However, separation often raises far larger questions. As humans, we have evolved along with plants and animals as our food sources. The evidence is now clear that diet-related illnesses have increased dramatically as societies have shifted from diets made up of locally grown, raw, and minimally processed plant- and animal-based foods to industrially produced, processed, and manufactured foods (World Health O rganization, n.d.). The economic costs of public health externalities are sometimes mentioned, though rarely estimated, but the total cost of human suffering from diet-related illnesses is incalculable.

The evolution of food systems obviously has become disconnected from evolution in the human species, and humanity is suffering the consequences. Furthermore, a fundamental challenge of the strategy of separation is that the problems related to our current food systems are inherent in the systems as wholes, rather than specific components or aspects of the systems. The mechanistic nature of today's industrial food systems inevitably conflicts with the organismic nature of the ecological and social systems within which they function. Attempts to solve specific problems to make systems less bad often create unintended consequences that instead make them worse.

A prime example is the pervasive use of the herbicide glyphosate. When it came on the market in the 1970s, it was heralded as an environmentally benign alternative to toxic herbicides and was promoted as a practical tool for conservation tillage. However, glyphosate was recently labeled as "probably carcinogenic" - after becoming ubiquitous in our environment (World Health Association, 2015). In addition, reduced tillage systems simplified crop production, allowing farms to become still larger and fewer-continuing the economic and social decline of rural communities. Systemic problems are sometimes referred to as "wicked problems." (Ikerd, 2016a). They are characteristic of problems with complex, interconnected, dynamic systems, such as the agri-food system. Systemic problems are extremely difficult, if not impossible, to solve- without changing the whole system.

Another potentially fatal problem of the industrial food system is that it has failed to provide food security, as I have emphasized in previous columns (Ikerd, 2016b). This again is a reflection of a fundamental flaw in the system. The basic motivation for adopting industrial strategies of food production and distribution is to improve economic efficiency, and it was argued that this would lead to improved food security. O ver time, the economic advantages of specialized, mechanized, large-scale production have been transformed into political advantages. Resulting farm and food policies have allowed industrial systems to persist, in spite of their negative impacts on nature and society. These are natural consequences of systems where economic efficiency is allowed to take priority over social and ethical responsibility. A food system driven by individual economic self-interests will neither ensure healthful, nutritious foods for anyone nor meet the basic nutritional needs of everyone.

In my previous column, I suggested that the logical alternative to the current industrial agri-food production are systems that reconnect and integrate farming and food production with nature and society. O rganic, ecological, biological, holistic, regenerative, and other promising alternatives to industrial agriculture share the basic principles of "agroecology." Agroecology recognizes and respects the inherent interconnectedness of agri- 
food systems with the natural and social environments within which they function. If such alternatives prove successful, they will avoid, rather than solve, the ecological and social problems inherent in the industrial agri-food system.

However, agroecological agri-food systems still face many of the same challenges as the current food system. First, the fundamental purpose of food production and distribution is food security, meaning that there is enough safe, wholesome food to meet the basic nutritional needs of everyone. An agri-food system that cannot meet the needs of the present, as well as the future, is not sustainable. Global research has shown that agroecological farming systems are capable of sufficient expansion in production to meet global food demands (International Panel of Experts on Sustainable Food Systems, 2016). However, the question remains of whether the research results for individual farms and farmers can be replicated and extended to enough farms and farmers to essentially replace the current industrial food system.

Perhaps the greatest challenge in replacing the industrial food system is economic viability. In meeting this challenge, economic efficiency and profitability must be accepted as a means of ensuring food security, rather than the purpose or primary motivation for engaging in food production. As experiences of past decades have proven, "cheap foods" produced by profit-driven systems are not a solution to hunger or food insecurity. The food sovereignty movement is an attempt to insulate local food security from profit-driven economies and to integrate food production with local ecological and socioeconomic communities. Food sovereignty would ensure both food security for local consumers and economic viability for local farmers as basic human rights (Ikerd, 2016b). Admittedly, food sovereignty in America will require a major cultural shift, but such a shift could logically begin with individual bioregions and communities.

Finally, there seems to be no middle ground between separation and integration. As industrial producers move toward integrated agri-food systems, they eventually compromise their economic efficiency. They lose their ability to compete for consumers who prioritize low prices, but they are too large to survive in niche markets. As agroecological producers specialize, standardize, and scale up to gain economic efficiency, they eventually compromise their integrality with local ecosystems and communities and become less "different." They lose their ability to compete for customers willing to pay premium prices for foods with ecological and social integrity, but are too small to compete in mass markets.

That being said, the vast majority of U.S. farmers are still small enough to transition from producing commodities for global markets to producing foods for their local communities or bioregions. G overnment farm programs have subsidized the development of industrial agriculture and could be equally effective in supporting a transition to sustainable agriculture. Over time, differences in production costs would shrink, if not disappear. The greatest challenge of localization over the long run will be to reduce the costs of local processing and distribution. This will require cooperation among local producers to realize affordable economies of scale without sacrificing their local identity. Local foods must be affordable but need not be cheap.

Local food systems will always require some degree of insulation from the competitive pressures of global markets to maintain their ecological and social integrity. Regardless, there seems to be little choice other than to either separate or integrate. The future of nature and humanity depends on farmers and food producers- and consumers making the right choice. 


\section{References}

Ikerd, J. (2016a, July 3). Solving widk ed problems [Blog post]. Retrieved from http:/ / johnikerd.com/ 2016/ 07/ solving-wicked-problems/

Ikerd, J. (2016b). Food sovereignty: New mandate for food and farm policy. Journal of A griculture, Food Systems, and C ommunity D evelopment, 5(2), 11-14. https:/ / doi.org/ 10.5304/ jafscd.2015.052.004

International Panel of Experts on Sustainable Food Systems [IPES-Food]. (2016). F rom uniformity to diversity: A paradigm shitt from industrial agriculture to diversified agroecological system. Retrieved from http:/ / www.ipes-food.org/ images/ Reports/UniformityToDiversity_FullReport.pdf

Locke, S. (2016, November 7). F ood and agriculture ompanies seak ing to secure future food supply pitch innovative ideas. ABC News, Australia. Retrieved from https:/ / www.abc.net.au/ news/ rural/ 2016-11-07/ food-bytes-innovation-to-unlockgreater-food-production/ 8001442

World Health Organization. (n.d.). Back ground: The global burden of chronic [diseases]. Retrieved from http:// www.who.int/ nutrition/ topics/ 2 background/ en/

World Health Organization. (2015). E valuation of five organophosphate insecticides and herbicides (IARC Monograph Volume 112). International Agency for Research on Cancer, World Health Organization. Retrieved from http:// www.iarc.fr/ en/ media-centre/ iarcnews/ pdf/ MonographVolume112.pdf 